\title{
Abundance and dynamics of free flagellate scales in marine costal ecosystems
}

\author{
Harald Landa, Gunnar Bratbak, Mikal Heldal*
}

Department of Microbiology, University of Bergen, Jahnebakken 5, 5020 Bergen, Norway

\begin{abstract}
Some groups of algae form extracellular scales of organic or inorganic material as part of their extracellular matrix, and such scales, shed from algae, are frequently observed by electron microscopy in marine water samples. However, virtually nothing is known about the production and fate of algal scales in natural ecosystems. In this study we demonstrate the seasonal variation of free scales in Norwegian coastal waters and their short time dynamics (3 wk) in enclosed water masses with artificially induced phytoplankton blooms. In addition we estimate decay rates of free scales under laboratory conditions. The total abundance of scales was $3 \times 10^{4}$ to $1.2 \times 10^{6} \mathrm{ml}^{-1}$ in the coastal ecosystem we studied and we could follow the dynamics of free scales from different species of Pyramimonas, Heterocapsa and Chrysochromulina. From laboratory incubation we measured decay rates of free scales in the range of -0.01 to $-0.02 \mathrm{~d}^{-1}$. The mechanism for disappearance of algal scales seems to be a combined effect of degradation and aggregation.
\end{abstract}

KEY WORDS: Microalgae · Scales · Transmission electron microscopy · TEM · Marine particles Resale or republication not permitted without written consent of the publisher

\section{INTRODUCTION}

Some groups of algae form extracellular scales of organic or inorganic material as part of their extracellular matrix. Inorganic silicified scales are formed by some Chrysophyceae, while calcified scales are formed by some of the Prymnesiophyceae. Organic scales are formed by several groups and species among the Dinophyceae, Prasinophyceae and Prymnesiophyceae (Tomas 1997). The size of the organic scale types ranges from $<20$ to $>1 \mu \mathrm{m}$ in diameter and up to $>30 \mu \mathrm{m}$ in length (Green et al. 1990). Scales in the lower size range are mainly flagella scales, while body scales belong to the fraction of larger scales. The prasinophytes usually have 2 types of scales: large body scales and tiny flagellar scales. The scales of the prymnesiophytes are more diverse, and each species may have several different scale types and sizes. The size and morphology of the scales are characteristic for species and are thus used as taxonomic criteria (e.g. Manton \& Parke 1962).

The chemical composition of organic algal scales has been studied for a few species including Pleurochrysis scherffelii Pringsheim (Romanovicz \& Brown 1976), Chrysochromulina chiton Parke \& Manton (Allen \& Northcote 1975), Pyramimonas pseudoparkeae Pienaar \& Aken (Aken \& Pienaar 1985), Mesostigma viride Lauterborn (Domozych et al. 1991) and Tetraselmis striata Butcher (Becker et al. 1989). In summary, the composition is dominated by protein and carbohydrates, and for different scale types the protein content has been reported to range from about 3 to $65 \%$, while the carbohydrate content ranges from about 30 to $>90 \%$.

From our transmission electron microscope (TEM)based studies of microbial communities in marine waters, we have often observed a significant abundance of free algal scales (e.g. Bergh et al. 1989, Bratbak et al. 1990, 1992). Free scales in the water column may be the result of a continuous production and shedding of scales during growth, grazing, or from viral lysis of cells. Since the scale formation in any case is species-specific, their occurrence represents a fingerprint of the algal species that are, or that have been, present in the ecosystem. In this context the turnover and decay rate of the scales becomes a key issue. 


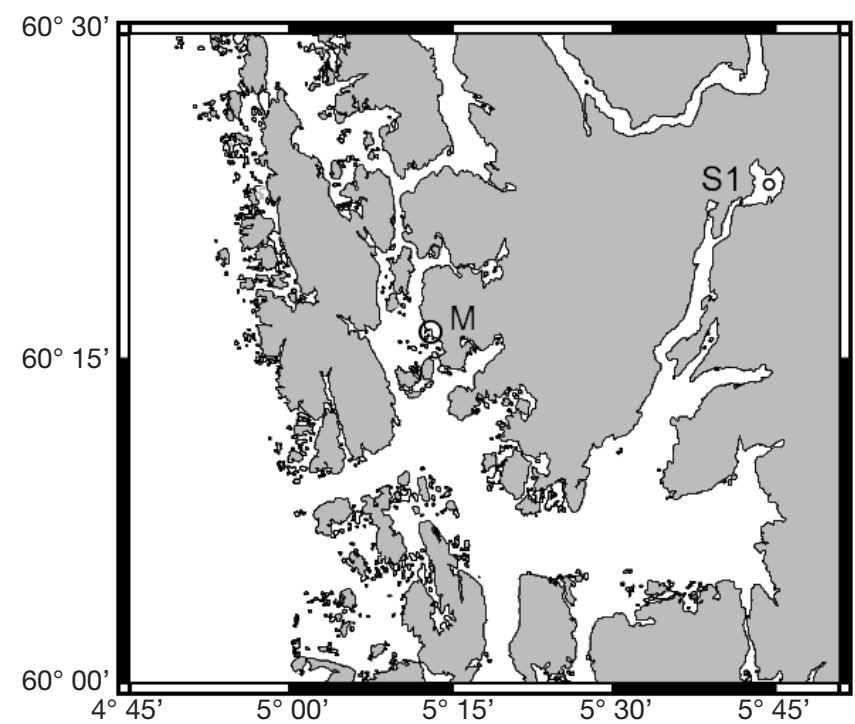

Fig. 1. Map of the Norwegian coastal area included in this study. M: biological station Espegrend, the site for mesocosm studies. S1: sampling station in Samnangerfjorden

In this paper we have studied the seasonal variation of free scales in Norwegian coastal waters and their short time dynamics ( $3 \mathrm{wk}$ ) in enclosed water masses with artificially induced phytoplankton blooms. The decay rate of different scale types was determined by laboratory incubations.

\section{MATERIALS AND METHODS}

Field studies. Temporal changes in abundance of different scale types were studied on 2 occasions in Norwegian coastal waters: (1) in open water masses of the fjord Samnangerfjorden during a seasonal field campaign (15 April to 21 October 1999) (Fig. 1); and (2) in enclosed water masses during a mesocosm experiment in Raunefjorden at the Marine Biological Field Station (16 April to 6 May 1999) (Fig. 1; see also www.ifm.uib.no/lsf/inst2.html).

In Samnangerfjorden we collected water samples at 2 to 4 wk intervals at the depth of the chlorophyll maximum determined by in situ fluorescence (Seabird SBE911plus with Sea Tech Fluorometer or STD SAIV a/s SD 204 with Sea Point fluorometer).

The enclosures used in the mesocosm experiment were $4 \mathrm{~m}$ deep and $2 \mathrm{~m}$ wide (volume: $11 \mathrm{~m}^{3}$ ) and made of $0.15 \mathrm{~mm}$ thick polyethylene $(90 \%$ light penetration, PAR). They were filled with seawater from $2 \mathrm{~m}$ depths. An airlift system in each enclosure was used to ensure mixing of the water during the experiment (Larsen et al. 2001). We sampled 5 enclosures treated to obtain different population densities and community compo- sition. Three enclosures (N2, NU1 and NU2) were enriched with nitrate and phosphate on Day 1 to a final concentration of $8 \mu \mathrm{M} \mathrm{NaNO}$ and $0.5 \mu \mathrm{M} \mathrm{K} \mathrm{K}_{2} \mathrm{HPO}_{4}$. One enclosure (N1) was delayed and received the initial nutrient enrichment on Day 4. To avoid nutrient limitation, extra nutrients were added on Days 7 and 13 (4 $\mu \mathrm{M} \mathrm{NaNO}{ }_{3}$ and $0.25 \mu \mathrm{M} \mathrm{K}_{2} \mathrm{HPO}_{4}$ ). The enclosures NU1 and NU2 were, in addition to being enriched with nutrients, also exposed to UV radiation. This treatment was given by pumping $0.6 \mathrm{~m}^{3}$ water through a UV radiation unit during a $1 \mathrm{~h}$ period each night. The UV unit used had a $115 \mathrm{~W}$ UV-C fluorescent tube with reflector (Philips TUV 115W R VHO), which provided an average dose of $5 \mathrm{mWs} \mathrm{cm}^{-2}$. One enclosure served as control and received no treatment. The enclosures were sampled every second day.

Algal biomass in the enclosures was measured fluorometrically as chl a in a Turners Designs Fluorometer Model 10-AU after filtration onto Sartorius membrane filters $(0.45 \mu \mathrm{m})$ and extraction in $90 \%$ acetone (Parsons et al. 1984). All water samples from the field studies were brought back to the laboratory and prepared for counting of scales by transmission electron microscopy within $5 \mathrm{~h}$ after sampling.

Experimental studies. Decay of scales from natural communities: Water collected on Day 14 from each of the 4 nutrient-amended enclosures was transferred to $1 \mathrm{l}$ glass bottles and incubated at room temperature in the dark for $63 \mathrm{~d}$. Samples of $20 \mathrm{ml}$ were withdrawn from each bottle once a week, fixed with glutaraldehyde ( $2 \%$ final concentration) and stored at $4{ }^{\circ} \mathrm{C}$ until the end of the incubation period when they were prepared for counting of scales by TEM.

Decay of scales from Pyramimonas orientalis McFadden, Hill \& Wetherbee (Prasinophyceae): A $500 \mathrm{ml}$ monoculture of $P$. orientalis was lysed by adding a few $\mathrm{ml}$ of the species-specific virus PoV (Sandaa et al. 2001) and then centrifuging for $30 \mathrm{~min}$ at $7500 \mathrm{rpm}(10000 \times g)$ in a Beckman JS-7.5 swing out rotor. The supernatant and the top layer of the pellet containing scales were removed by a pipette, mixed and used in the subsequent decay experiments. Aliquots of this scale solution were added to 3 parallel 11 bottles containing aged seawater to give a final scale abundance of about $10^{9}$ scales $\mathrm{ml}^{-1}$. The aged seawater had a total organic carbon content of $2.1 \mathrm{mgC}$ $\mathrm{l}^{-1}$, and the concentration of soluble reactive phosphorus was $0.3 \mu \mathrm{M}$ P (Evy Foss Skjoldal pers. comm.). Three different incubation regimes were used in this experiment: Days 1 to 102 at 4 to $6^{\circ} \mathrm{C}$; Days 102 to 172 at room temperature; and Days 172 to 266 at room temperature and nutrient enrichment. The nutrients added on Day 172 were $1 \mathrm{mM} \mathrm{C}$ (glucose), $75 \mu \mathrm{M} \mathrm{N}\left(\mathrm{NH}_{4} \mathrm{Cl}\right.$ ) and $15 \mu \mathrm{MP}\left(\mathrm{K}_{2} \mathrm{PO}_{4}\right)$. All incubations were in the dark. The samples were diluted 1:10 in particle-free water 
before they were prepared for counting of scales by transmission electron microscopy.

Analysis. Particles in the water samples were harvested by centrifugation directly onto 400 mesh Ni-grids supported with carbon-coated formvar film (Bratbak \& Heldal 1993). All samples were centrifuged at $40000 \mathrm{rpm}(260000 \times g)$ for $30 \mathrm{~min}$ in a Beckman L8 ultracentrifuge equipped with a SW 41 Ti swing out rotor. The grids were air-dried and positive stained for $3 \mathrm{~min}$ with uranyl acetate ( $2 \% \mathrm{w} / \mathrm{w}$ in water) 4 to $6 \mathrm{~h}$ before counting. The total counts of scales were calculated as described in Bratbak \& Heldal (1993) from counts per view field in a JEOL 100S TEM operated at 30000 to $50000 \times$ magnification. We counted 20 to 200 fields of view on each sample and if attainable at least 200 scales.

\section{RESULTS}

Fig. 2 illustrates the diversity and morphology of algal scales in marine water samples. Most of the scale types we counted in this study are present in these images.

\section{Field studies}

Temporal changes in chl $a$ and abundance of different scale types in the open water masses of Samnangerfjorden are shown in Fig. 3. The main increases in chl a concentration occurred in April and in June. The abundance of free scales from different species of Pyramimonas increased in April and/or May from about $10^{4}$ to $5 \times 10^{5} \mathrm{ml}^{-1}$. A similar but less pronounced development was seen for scales of Heterocapsa sp. (Dinophyceae) and Chrysochromulina polylepis Manton \& Parke (Prymnesiophyceae). These scales peaked in abundance in late May and in July. From the peak values in late May to late September, the abundance of all scale types decreased at an average rate of $-0.008 \pm 0.003 \mathrm{~d}^{-1}$ (mean $\pm \mathrm{SD}, \mathrm{n}=5$, range -0.004 to $-0.012)$.

The overall development in phytoplankton biomass during the mesocosm experiment is illustrated by the chl a measurements (Fig. 4). The chl a concentration remained relatively low in the control enclosure ( 1 to $2 \mathrm{mg} \mathrm{l}^{-1}$ ), while in the nutrient-enriched enclosures the concentration increased and reached 8 to $10 \mathrm{mg} \mathrm{l}^{-1}$ after 12 to $14 \mathrm{~d}$. As expected and compared to Enclosure N2, the development in chl a concentration was delayed in Enclosure N1, and in the UV-treated enclosures (NU1 and NU2) it was more variable. The development in the 2 parallel UV-treated enclosures was very similar and demonstrates the reproducibility of the experiments and the chl a measurements.
Fig. 5 shows the net change in abundance of 6 different scale types during the $20 \mathrm{~d}$ mesocosm experiment. The overall abundance of scales was roughly 10 times higher in the nutrient-amended enclosures compared to the control enclosures, and the most pronounced increase in scales (i.e. scales of Pyramimonas cirolanae Pennick) was delayed in N1 compared to N2 and NU (NU1 and NU2). The development in the different enclosures with respect to scale concentration was thus in general agreement with the development in chl a concentration (Fig. 4).

Scales of Heterocapsa sp., Pyramimonas sp. and Pyramimonas cirolanae were dominant from the start of the experiment (Fig. 5). Pyramimonas sp. scales were initially the most abundant but they were outnumbered by $P$. cirolanae scales when the biomass in the enclosures started to increase. In the second half of the experiment, when the number of $P$. cirolanae scales peaked and started to decrease, there was a marked increase in Heterocapsa sp. and Pyramimonas sp. scales in Enclosures NU1 and NU2 that was not paralleled by similar increases in N1 or N2. From Day 5 on we found an increasing abundance of Chrysochromulina polylepis and Chrysochromulina sp. scales in all enclosures. Thus, there were considerable differences in population densities and community composition in the different enclosures, as intended by the experimental design.

In Enclosure N1, the algal community included a mixture of several species of diatoms, dinoflagellates and other flagellates (Larsen et al. 2001). On Day 15 the community included 7 different diatoms $\left(3.0 \times 10^{3} \mathrm{cells} \mathrm{m}^{-1}\right)$ and 13 different dinoflagellates, among which Heterocapsa rotundata (Lohmann) Hansen made up the majority $\left(2.8 \times 10^{3} \mathrm{ml}^{-1}\right)$. The abundance of Heterocapsa sp. scales on Day 15 was $6.9 \times 10^{4} \mathrm{ml}^{-1}$ and increasing (Fig. 5). Other flagellates were the most abundant forms and 2 to $5 \mu \mathrm{m}$ sized unidentified flagellates, mostly with Prymnesiophyceae-like chloroplasts, peaked on Day 13 $\left(9 \times 10^{4}\right.$ cells ml $\left.{ }^{-1}\right)$. The abundance of 2 different Chrysochromulina polylepis plate scales on Day 13 was $8.6 \times 10^{4}$ and $4.3 \times 10^{4} \mathrm{ml}^{-1}$ and the abundance of Chrysochromulina sp. scales was $1.6 \times 10^{5} \mathrm{ml}^{-1}$ (Fig. 5). Pyramimonas sp. and 6 to $10 \mu \mathrm{m}$ sized unidentified prasinophytes reached maximum abundance on Day 15 with $3 \times 10^{4}$ and $9 \times 10^{3}$ cells ml $^{-1}$, respectively. The abundance of $P$. cirolanae scales on Day 15 reached a maximum value of $7.0 \times 10^{6} \mathrm{ml}^{-1}$, while the abundance of Pyramimonas sp. scales was $2.3 \times 10^{6} \mathrm{ml}^{-1}$ and still slightly increasing (Fig. 5). In summary, for Heterocapsa spp. and Pyramimonas spp. the abundance of free scales in the water was 25 to 310 times as high as the abundance of cells. The abundance of Chrysochromulina sp. scales was 3 times the abundance of all cells with Prymnesiophyceae-like chloroplasts. 


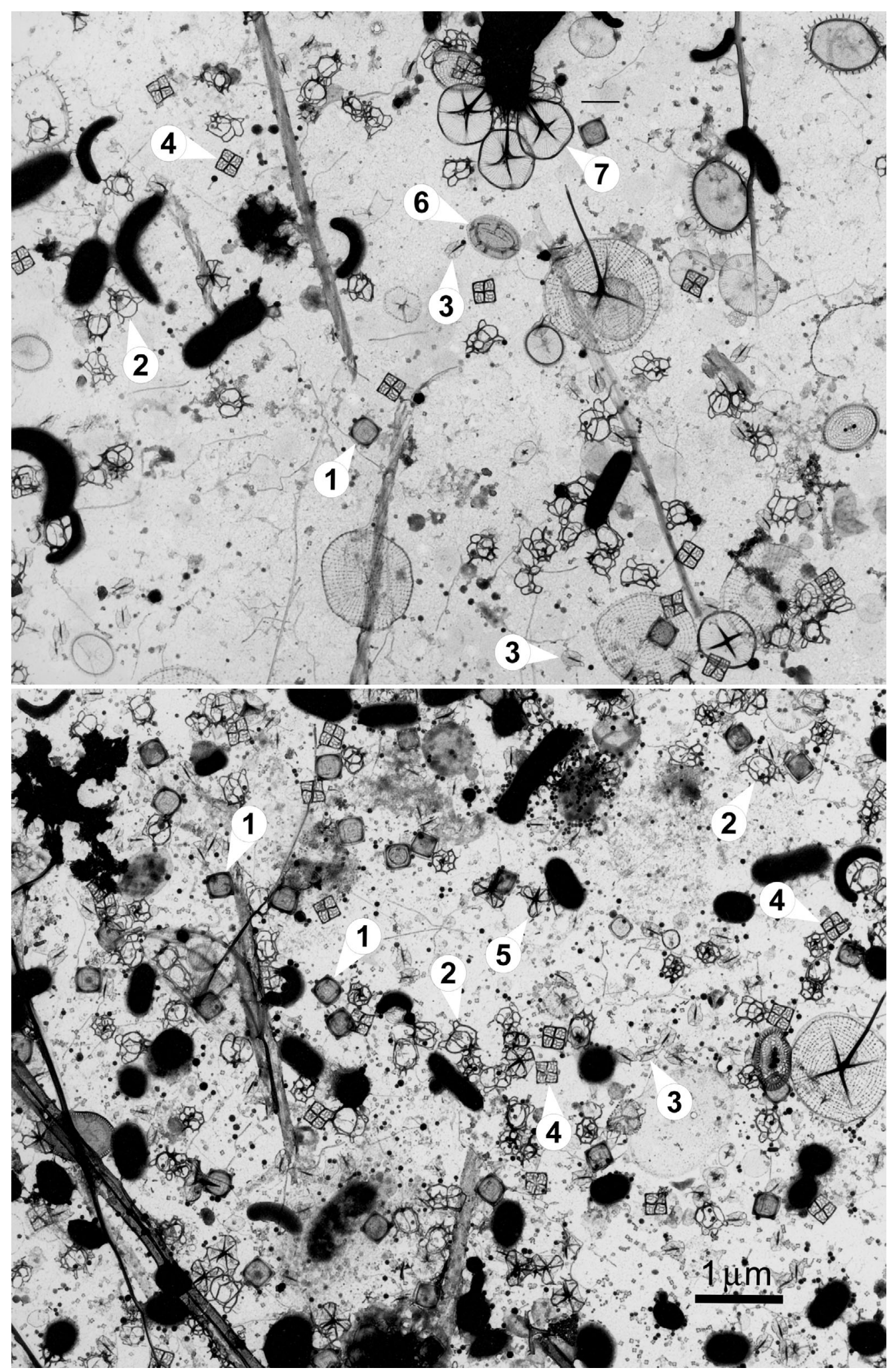

Fig. 2. Transmission electron microscopy micrographs of particles harvested from the mesocosm experiments at Espegrend on May 6, 1999, illustrating some scales and groups of scales from species included in this study. 1 to 3: scales from Pyramimonas orientalis, i.e. box scale (1), crown scale (2) and limuloid scale (3); 4: box scale from Pyramimonas cirolanae; 5: from Heterocapsa sp.; 6 and 7: from Chrysocromulina sp. 


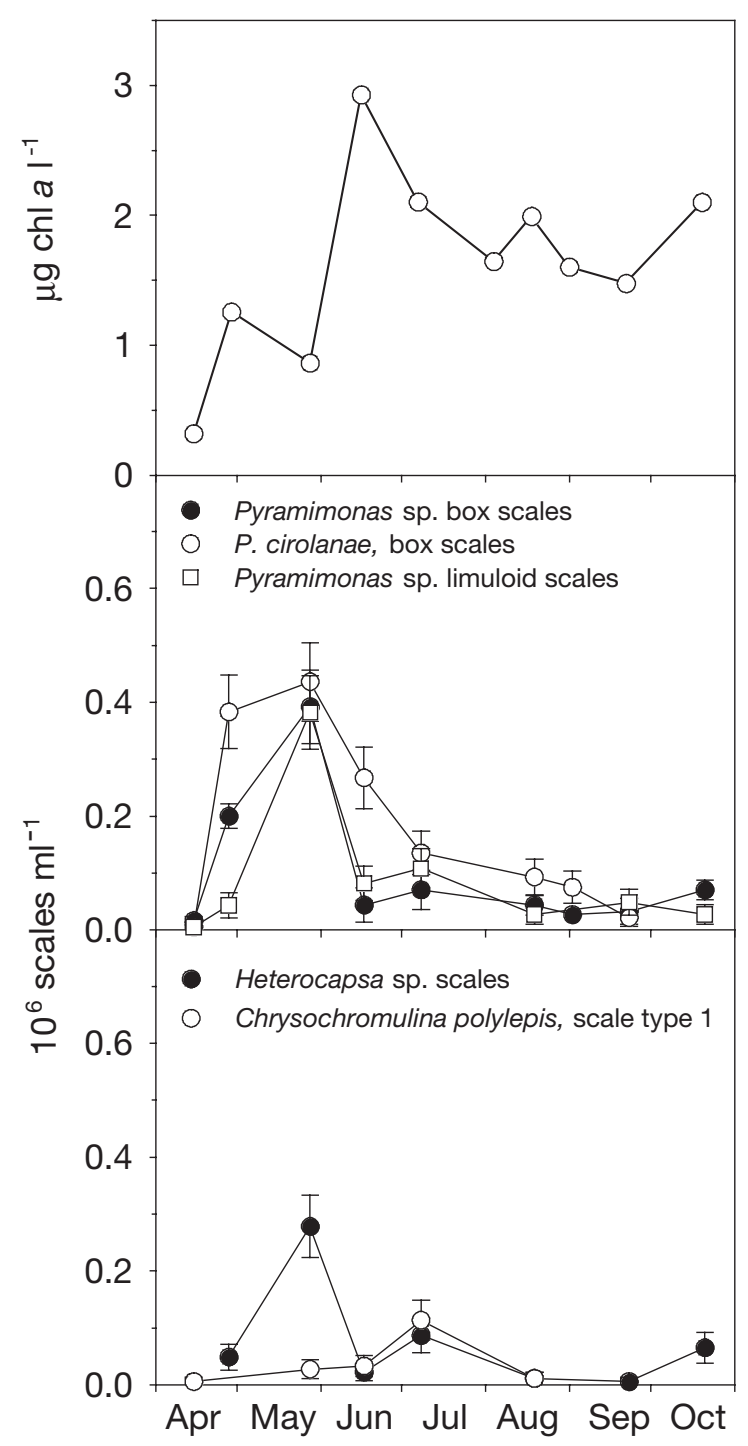

Fig. 3. Seasonal changes in chl a and abundance of different scale types in the open water masses of Samnangerfjorden (see Fig. 1). Error bars represent counting error

When the concentration of Heterocapsa sp., Pyramimonas sp. and Pyramimonas cirolanae scales started to decrease in the control enclosure (Fig. 5), the rates of decrease were $-0.09 \pm 0.01,-0.04 \pm 0.007$ and $-0.07 \pm$ $0.02 \mathrm{~d}^{-1}$ (mean $\left.\pm \mathrm{SE}\right)$, respectively. These rates are higher than in the nutrient-amended enclosures (N1, N2 and NU1, NU2), where the concentration of $P$. cirolanae scales decreased at a rate of $-0.02 \pm 0.01 \mathrm{~d}^{-1}$ (mean $\pm \mathrm{SD}, \mathrm{n}=4$, range -0.01 to -0.03 ) after the peak concentration. These rates are based on net change in scale abundance, and assuming that the rate of scale removal is the same in all enclosures we interpreted these results to indicate that there was some production of scales in the nutrient-amended enclosures throughout the entire experimental period.

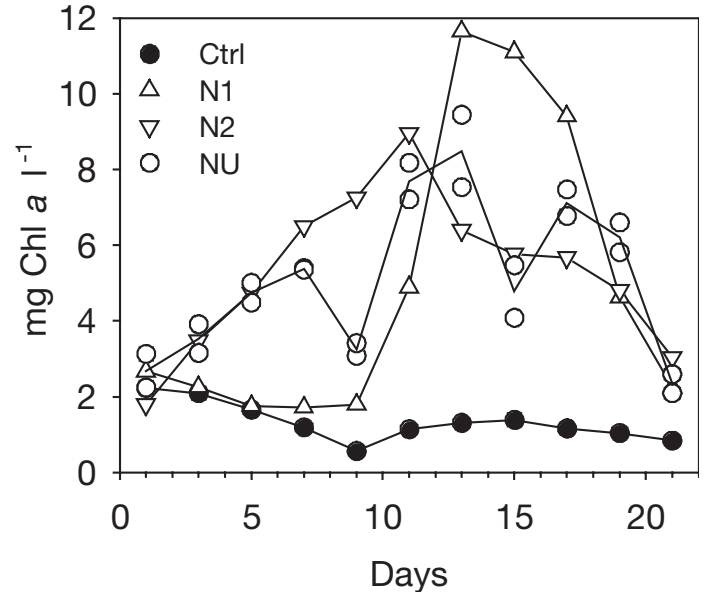

Fig. 4. Biomass ( $\mathrm{chl} \mathrm{a)} \mathrm{in} \mathrm{the} \mathrm{mesocosm} \mathrm{experiments} \mathrm{April} \mathrm{to}$ May 1999. The control enclosure (Ctrl) received no treatment. Enclosure N2 received nutrients ( $\mathrm{N}$ and $\mathrm{P}$ ) on Day 1 and Enclosure N1 received nutrients ( $\mathrm{N}$ and $\mathrm{P}$ ) on Day 4. NU includes 2 parallel enclosures (NU1 and NU2) that received nutrients on Day 1 and in addition were exposed to UV radiation (for details see 'Materials and methods')

\section{Experimental studies}

Decay of scales from natural communities

Fig. 6 shows that the abundance of Pyramimonas cirolanae box scales and 3 different $P$. orientalis scales decreased by 1 to 2 orders of magnitude when incubated for $63 \mathrm{~d}$ under laboratory conditions. The average loss rate for the 4 different scale types was $-0.020 \pm 0.002 \mathrm{~d}^{-1}$ (mean $\pm \mathrm{SD}$ ) and the range was -0.022 to $-0.018 \mathrm{~d}^{-1}$.

\section{Decay of scales from Pyramimonas orientalis}

Fig. 7 shows the decay of 3 different Pyramimonas orientalis scales under different conditions. In aged seawater at 4 to $6^{\circ} \mathrm{C}$ (Days 1 to 102) we observed no significant loss, while at room temperature (Days 102 to 266 ) the loss rate for the 3 scale types was $-0.01 \pm$ $0.001 \mathrm{~d}^{-1}$ (mean $\pm \mathrm{SD}, \mathrm{n}=3$ ). Carbon and nutrient addition at Day 172 did not change the loss rate significantly ( $t$-test, $\mathrm{p}>0.05$ ).

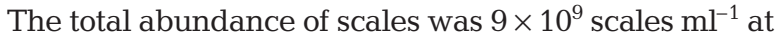
the start of the experiment. The contrast of the scales as they appeared in the TEM decreased throughout the incubation period. This indicates that they lost mass and in part we attribute the decrease in abundance of free scales to this process. Moreover, scales that were partially disrupted, and decaying scales in loose aggregates that were 10 to $20 \mu \mathrm{m}$ in size (Fig. 8) became more numerous throughout. We did not observe any frequent direct contact between bacteria and scales in our preparations. 


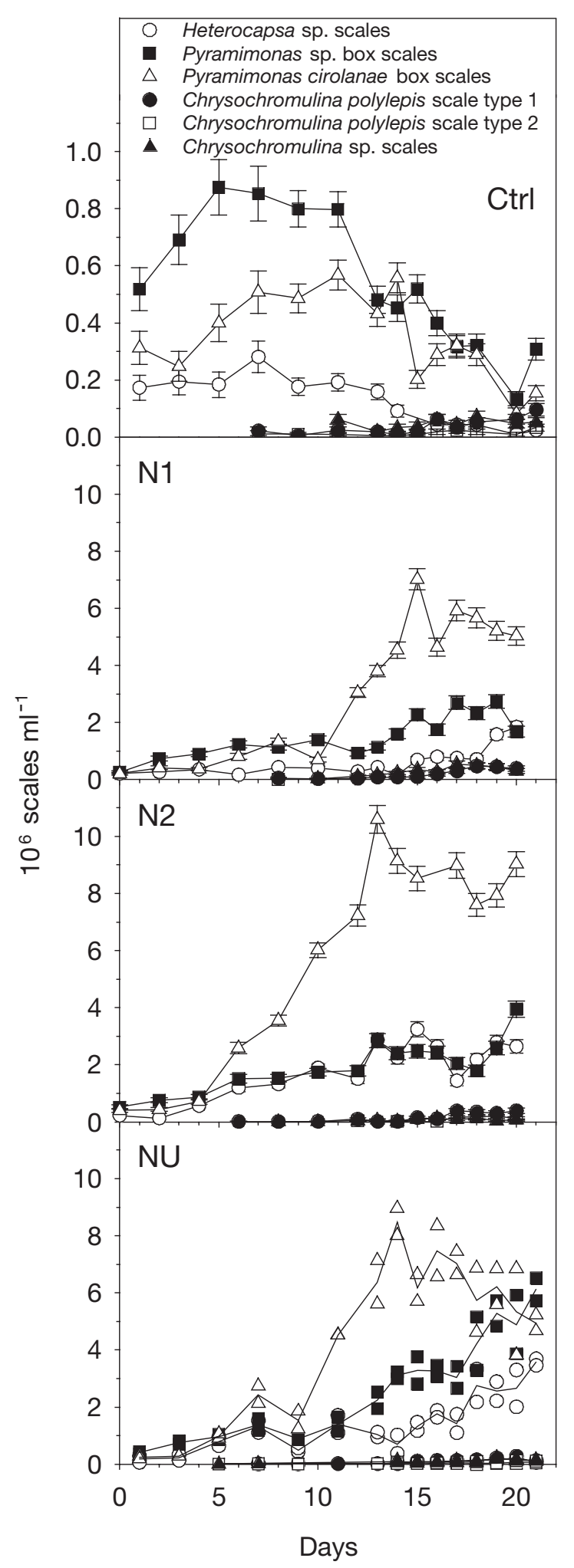

Fig. 5. Development of 6 different scale types representing 5 different algal species in mesocosm enclosures receiving 4 different treatments (Ctrl, N1, N2 and NU, see Fig. 4). Error bars represent counting error. NU includes 2 parallel enclosures (error bars removed for clarity)

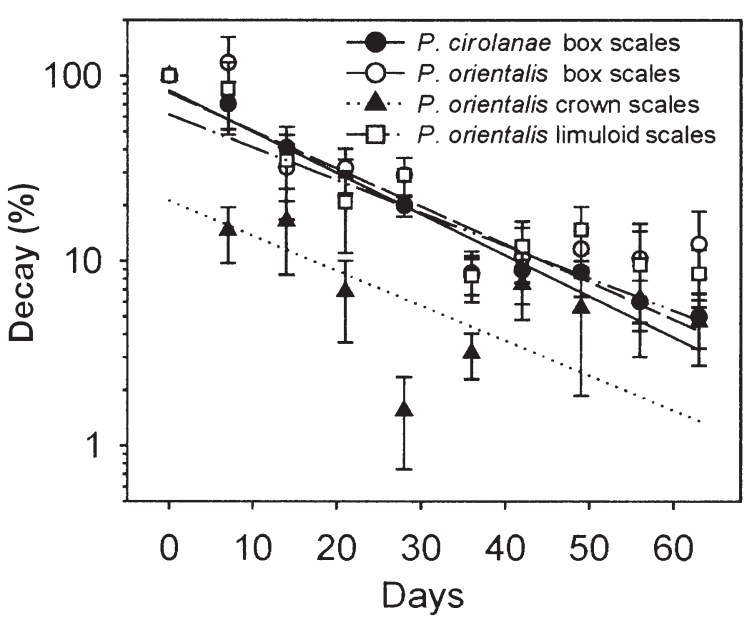

Fig. 6. Decay of 4 different scale types from 2 algal species (Pyramimonas cirolanae and P. orientalis) shown as percentage of scales remaining versus time. Samples for this experiment were collected from the mesocosm enclosures on Day 14 and incubated at room temperature in the dark for $63 \mathrm{~d}$. Symbols represent the mean of 4 incubations and error bars represent \pm SE. Lines are linear regression based on all data for each scale type

\section{DISCUSSION}

Seasonal variation and short time dynamics of different scale types originating from various flagellate species were demonstrated by our studies in Samnangerfjorden and in the mesocosm experiments.

The total abundance of scales was $3 \times 10^{4}$ to $1.2 \times 10^{6}$ $\mathrm{ml}^{-1}$ in Samnangerfjorden and $7 \times 10^{5}$ to $1.6 \times 10^{7} \mathrm{ml}^{-1}$ in the mesocosm experiments. The corresponding chl a values were 0.3 to 3 and 0.6 to $12 \mu \mathrm{g} \mathrm{l} \mathrm{l}^{-1}$. There was a significant correlation between the total abundance of scales and chl $a$ in the mesocosm experiments $(\mathrm{R}=$ 0.464, $\mathrm{p}<0.0004$, df = 52) but not in Samnangerfjorden $(\mathrm{R}=-0.191, \mathrm{p}<0.6, \mathrm{df}=7)$. Pyramimonas, Heterocapsa and Chrysochromulina species were the dominating scale-producing algae both in the mesocosms and in Samnangerfjorden, but they made up only a small fraction of the total algal biomass (i.e. chl a). The correlation between scale abundance and chl $a$ in the mesocosms is therefore interpreted as a covariance between the algal populations producing scales and the populations dominating the biomass. With vertical mixing and horizontal water transport, Samnangerfjorden is a more complex environment than the mesocosms. In addition, the sampling intervals were much longer in Samnangerfjorden than in the mesocosm study (1 to $2 \mathrm{~d}$ vs 2 to $4 \mathrm{wk}$ ) and the data set is rather limited; therefore, no relationship between scale abundance and chl a concentration is to be expected.

The number of body scales per cell may be estimated from the size of the cells and the size of the scales that 


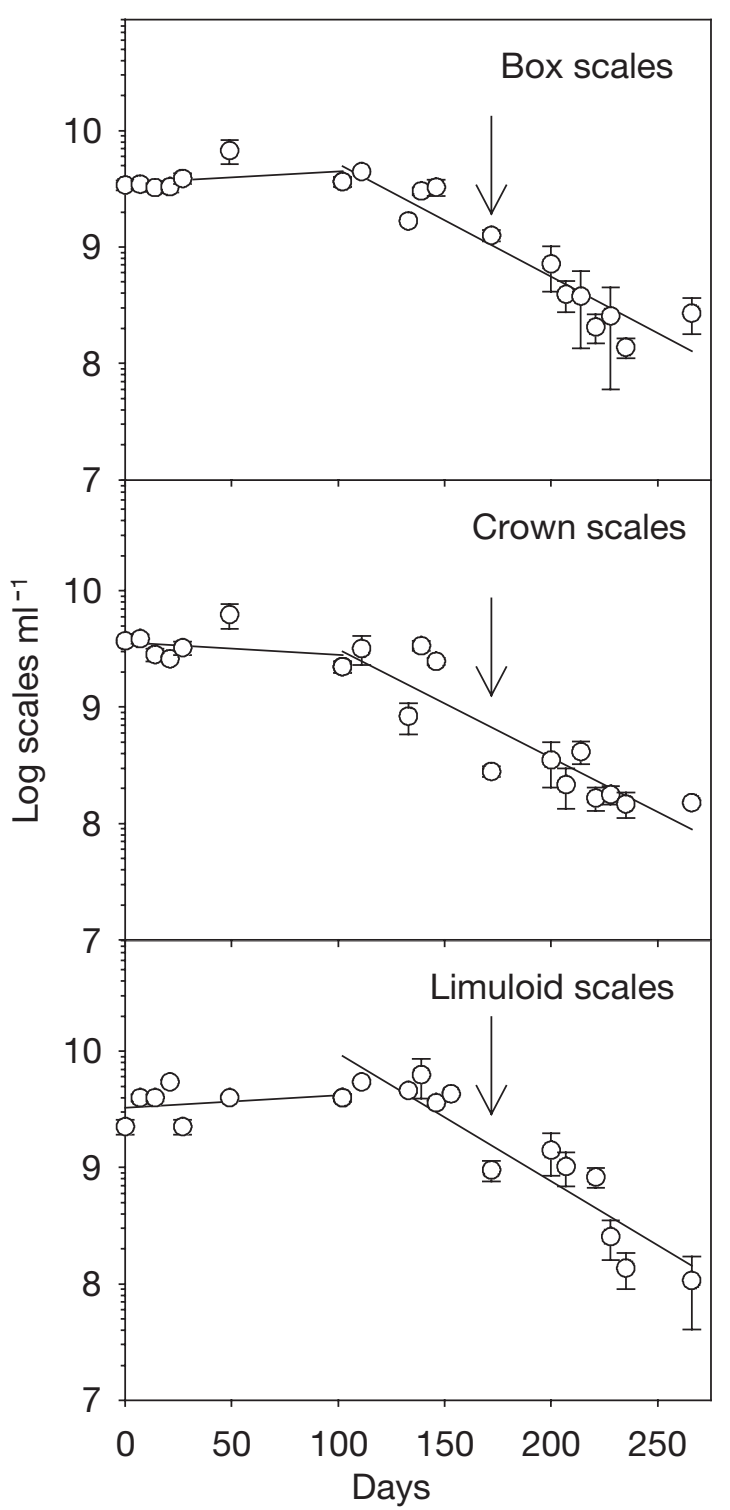

Fig. 7. Pyramimonas orientalis. Decay of 3 different scale types. Three different incubation regimes were used: Days 1 to 102 at 4 to $6^{\circ} \mathrm{C}_{\text {; }}$ Days 102 to 172 at room temperature; and Days 172 to 266 at room temperature and with nutrient enrichment (glucose, $\mathrm{N}$ and $\mathrm{P}$, for details see 'Materials and methods'). Arrows indicate nutrient addition. Lines are linear regression for Days 1 to 102 and for Days 102 to 266

cover the cell surface. Moestrup \& Walne (1979) estimated that Pyramimonas tetrarhynchus Schmarda, with a cell size of $22 \times 15 \mu \mathrm{m}$ (length $\times$ width) and a total surface area of approximately $1200 \mu^{2}$, is covered by about 6800 each of outer and inner body scales (OBS and IBS, respectively) that are $0.42 \mu \mathrm{m}$ wide (i.e. $0.18 \mu \mathrm{m}^{2}$ ). P. orientalis, which is about $7 \times 5 \mu \mathrm{m}$ (length $\times$ width), may be estimated to have a surface area of about $100 \mu \mathrm{m}^{2}$ and to be covered by about 1000 box scales that are approximately $0.3 \mu \mathrm{m}$ wide (i.e. $\left.0.09 \mu^{2}\right)$. The small $(<4 \mu \mathrm{m})$ species $P$. cirolanae (Backe-Hansen \& Throndsen 2002) will likewise have about 500 scales per cell. In Enclosure N1 the maximum abundance of free $P$. cirolanae box scales was $7.0 \times 10^{6} \mathrm{ml}^{-1}$ and the maximum abundance of free Pyramimonas sp. box scales was $2.7 \times 10^{6} \mathrm{ml}^{-1}$. If free scales are released only when cells die, we may estimate that these scales were produced at the expense of about $1 \times 10^{4} \mathrm{P}$. cirolanae cells ml ${ }^{-1}$ and 3000 Pyramimonas sp. cells $\mathrm{ml}^{-1}$ (assuming $P$. orientalis with 1000 scales per cell to be typical for Pyramimonas sp.). These cell losses are about 30 and $10 \%$ of the maximum abundance of Pyramimonas sp. cells $\left(3 \times 10^{4}\right.$ cells $\mathrm{ml}^{-1}$ ) in N1. In the open waters of Samnangerfjorden the maximum abundance of Pyramimonas sp. box scales and $P$. cirolanae box scales was $4.4 \times 10^{5}$ and 3.9 $\times 10^{5} \mathrm{ml}^{-1}$ respectively. With the same assumptions as above, these scales were produced at the expense of about 400 Pyramimonas sp. cells $\mathrm{ml}^{-1}$ and $1000 P$. cirolanae cells ml ${ }^{-1}$.

Under experimental conditions we determined loss rates in the range of -0.01 to $-0.03 \mathrm{~d}^{-1}$ for all types of scales. At low temperature and low bacterial activity (in aged seawater, 1 to $2 \times 10^{5}$ bacteria $\mathrm{ml}^{-1}$; data not shown) the scales seem to be quite enduring. Stimulating bacterial activity by adding nutrients did not increase the degradation of scales. One interpretation of this is that the scales are built of recalcitrant organic material and that the degradation rate is limited by steric hindrance. If the scales are assumed to be

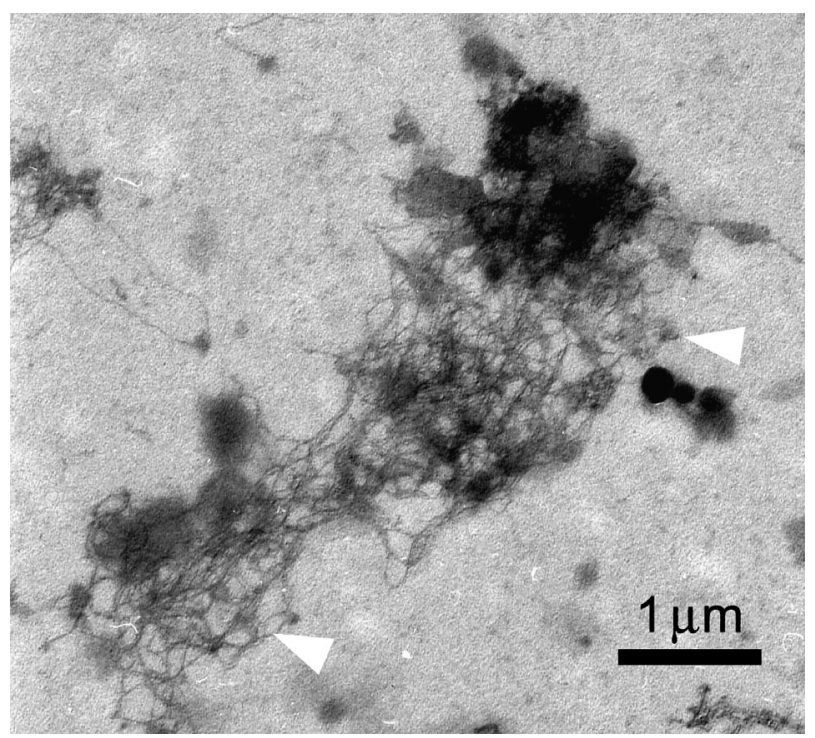

Fig. 8. Electron micrograph (TEM) of organic aggregates formed during incubation of samples from the mesocosm experiment. Arrowheads point out structures that may originate from algal scales 
polyanionic polysaccharide-calcium complexes they may act as chelators in seawater and tend to form aggregates, which in turn results in a decrease in abundance of free scales. From the incubation experiments of scales from the mesocosm experiments, we observed loose aggregates of organic material in the size range of 10 to $20 \mu \mathrm{m}$, and these aggregates seem to a large extent to consist of decaying algal scales (Fig. 8). The observed decrease in the abundance of free scales that we have called decay in this study may thus be a combination of decomposition and aggregation.

The main conclusions that can be drawn from this study are that algal scales are abundant in natural waters and that they have a relatively slow decay rate. They represent a species-specific fingerprint of the algal flagellate community that is, or that has recently been, present in the water and their abundance reflects the abundance of the algal species from which they are shed. Since some flagellate species can only be recognized by their scale morphology, observation of free scales in transmission electron microscopy conveys information to support observation and enumeration of plankton done by traditional light microscopy. In order to evaluate and interpret quantitative data on free algal scales in natural waters we need more basic data on the rate of scale production and on how many scales of different types the various species have. We also need a better understanding of the factors that determine release of scales from cells.

Acknowledgements. The electron microscopy work was done at the Laboratory for Electron Microscopy, University of Bergen, Norway, and we thank E. S. Erichsen for skilful help. We also thank J. Trondsen and W. Eikrem for their evaluation of algal taxonomy related to scale structures, and S. R. Erga for chlorophyll data from Samnangerfjorden. Two anonymous reviewers are thanked for their helpful comments and suggestions. This work was in part financed by the EC through the project DOMAINE (EVK3-CT-2000-00034) and by The Research Council of Norway through the project Biodiversity Patterns (158936/I10).

\section{LITERATURE CITED}

Aken ME, Pienaar RN (1985) Preliminary investigations on the chemical composition of the scale-boundary and cyst wall of Pyramimonas pseudoparkeae (Prasinophyceae). S Afr J Bot 51:408-416

Editorial responsibility: David Caron,

Los Angeles, California, USA
Allen DM, Northcote DH (1975) The scales of Chrysochromulina chiton. Protoplasma 83:389-412

Backe-Hansen P, Throndsen J (2002) Pico- and nanoplankton from the inner Oslofjord, eastern Norway, including description of two new species of Lufisphaera (incerta sedis). Sarsia 87:55-64

Becker B, Hard K, Melkonian M, Kamerling JP, Vliegenthart JFG (1989) Identification of 3-deoxy-manno-2-octulosonic acid, 3-deoxy-5-o-methyl-manno-2-octulosonic acid and 3-deoxy-lyxo-2-heptulosaric acid in the cell-wall (theca) of the green-alga Tetraselmis striata Butcher (Prasinophyceae). Eur J Biochem 182:153-160

Bergh Ø, Børsheim KY, Bratbak G, Heldal M (1989) High abundance of viruses found in aquatic environments. Nature 340:467-468

Bratbak G , Heldal M (1993) Total counts of viruses in aquatic environments. In: Kemp PF, Sherr BF, Sherr EB, Cole JJ (eds) Handbook of methods in aquatic microbial ecology. Lewis Publishers, Boca Raton, FL, p 135-142

Bratbak G, Heldal M, Norland S, Thingstad TF (1990) Viruses as partners in spring bloom microbial trophodynamics. Appl Environ Microbiol 56:1400-1405

Bratbak G, Heldal M, Thingstad TF, Riemann B, Haslund OH (1992) Incorporation of viruses into the budget of microbial C-transfer. A first approach. Mar Ecol Prog Ser 83:273-280

Domozych DS, Wells B, Shaw PJ (1991) Basket scales of the green algae, Mesostigma viride: chemistry and ultrastructure. J Cell Sci 100:397-407

Green JC, Perch-Nielsen K, Westbroek P (1990) Phylum Prymnesiophyta. In: Margulis L, Corliss JO, Melkonian M, Chapman DS (eds) Handbook of Protoctista. Jones \& Barlett, Boston, MA, p 293-317

Larsen A, Castberg T, Sandaa RA, Brussaard CPD and 6 others (2001) Population dynamics and diversity of phytoplankton, bacteria and viruses in a seawater enclosure. Mar Ecol Prog Ser 221:47-57

Manton I, Parke M (1962) Preliminary observations on scales and their mode of origin in Chrysochromulina polylepis sp. nov. J Mar Biol Assoc UK 42:565-578

Moestrup Ø, Walne PL (1979) Studies on scale morphogenesis in the Golgi apparatus of Pyramimonas tetrarhynchus (Prasinophycea). J Cell Sci 36:437-459

Parsons TR, Maita Y, Lalli CM (1984) A manual of chemical and biological methods for seawater analysis. Pergamon Press, Oxford

Romanovicz DK, Brown RM (1976) Biogenesis and structure of Golgi-derived cellulosic scales in Pleurochrysis. II. Scale composition and supramolecular structure. Applied Polymer Symposium No 28:687-610. John Wiley \& Sons, New York

Sandaa RA, Heldal M, Castberg T, Thyrhaug R, Bratbak G (2001) Isolation and characterization of two viruses with large genome size infecting Chrysochromulina ericina (Prymnesiophyceae) and Pyramimonas orientalis (Prasinophyceae). Virology 290:272-280

Tomas CR (1997) Identifying marine phytoplankton. Academic Press, London

Submitted: May 7, 2004; Accepted: August 30, 2004

Proofs received from author(s): October 21, 2004 